\title{
Cyathea gigantea (Cyatheaceae) as an antimicrobial agent against multidrug resistant organisms
}

\author{
Kathakali Nath ${ }^{1}$, Anupam Das Talukdar2 ${ }^{2 *}$, Mrinal Kanti Bhattacharya ${ }^{3}$, Deepshikha Bhowmik' Shiela Chetri ${ }^{1}$, \\ Debarati Choudhury ${ }^{2}$, Abhijit Mitra ${ }^{2}$ and Nargis Alom Choudhury ${ }^{1}$
}

\begin{abstract}
Background: Rapid emergence of multidrug resistant (MDR) organisms in hospital and community settings often result into treatment failure, thus leading the clinicians with fewer treatment options. Cyathea gigantea, an ethnomedicinally important fern used in cuts and wound infections. So, if this medicinal plant is used in treating the MDR infections then it might bring certain relief in future treatment options.
\end{abstract}

Methods: Antibacterial activity of C. gigantea against MDR bacteria was assed using well diffusion and broth microdilution methods to determine the diameters of growth inhibition zones, minimum inhibitory concentration (MIC) and minimum bactericidal concentration (MBC). Synergistic activity was also determined with the conventional antibiotics by disc diffusion method followed by FIC index of each of the tested antibiotic was calculated. The active extract was then subjected to fractionation by column chromatography and antibacterial activity was done with each of the collected fractions.

Results: Crude extract of $C$. gigantea was found to be active against all the tested organisms. The MIC was $200 \mathrm{\mu g} / \mathrm{ml}$ against Gram-positive i.e., Staphylococcus aureus ATCC 25923 and $400 \mu \mathrm{g} / \mathrm{ml}$ against Gram-negative i.e., Escherichia coli ATCC 25922 and Pseudomonas aeruginosa PAO1, while the MBC was $400 \mathrm{\mu g} / \mathrm{ml}$ in case of Gram-positive and $800 \mu \mathrm{g} / \mathrm{ml}$ for Gram-negative. The synergistic activity revealed that the plant extract increased the antibacterial property of the studied antibiotics and the FIC index showed that significant synergistic activity was shown by ciprofloxacin followed by tetracycline, ampicillin and oxacillin. Antibacterial activity with the fractionated extract showed that the FR II, FR III and FR IV were active against both Grampositive and Gram-negative bacteria, whereas FR I, FR V and FR VI did not show antibacterial property against any of the tested bacteria.

Conclusions: Extracts of C. gigantea was found active against both selected Gram-positive and Gram-negative organisms and thus offers the scientific basis for the traditional use of the fern. The present study also provides the basis for future study to validate the possible use against multidrug resistant organisms.

Keywords: Cyathea gigantea, Cyatheaceae, Extracts, Antibiotics, MDR bacteria, Antibacterial, Synergy

\footnotetext{
* Correspondence: anupam@bioinfoaus.ac.in

${ }^{2}$ Department of Life Science and Bio informatics, Assam University, Silchar,

India

Full list of author information is available at the end of the article
}

(c) The Author(s). 2019 Open Access This article is distributed under the terms of the Creative Commons Attribution 4.0 International License (http://creativecommons.org/licenses/by/4.0/) which permits unrestricted use, distribution, and reproduction in any medium, provided you give appropriate credit to the original author(s) and the source, provide a link to the Creative Commons license, and indicate if changes were made. The Creative Commons Public Domain Dedication waiver (http://creativecommons.org/publicdomain/zero/1.0/) applies to the data made available in this article, unless otherwise stated. 


\section{Background}

The worldwide emergence of multidrug resistant bacteria is the primary cause of various treatment failure and thus leading the clinicians with fewer treatment options. Natural products of plant origin are sources of various secondary metabolites and thus known to possess potential antimicrobial properties. In particular, the drugs derived from natural products are important in the treatment of life-threatening conditions [1]. Hence, if medicinal plants are used in treating the MDR infections, they might bring certain relief in future treatment options.

The fern possesses an important role in folklore medicine although neglected in modern days. The family Cyatheaceae includes the worlds' tallest tree ferns. $C$. gigantea is an ethno-medicinal important fern and a native of Southern Assam [2].Paste of apical soft portion of caudex is applied on cuts and wounds which prevents microbial growth and inhibits abscess formation. The plant is also effective in immediate blood clotting [3-5]. Hentriacontane, âsitostanone, diploterol, sitosterol, hop29-ol and oleanolic acid were isolated from the hexanesoluble fraction of the tree fern, C. gigantea [6]. The phytochemical study showed the presence of steroid, flavonoid and saponin and TLC profiling of plant extracts in different solvent system confirms the presence of diverse group of phytochemicals [7].

Therefore, in this study an attempt has been taken to explore the antibacterial property of the fern $C$. gigantea available in Southern part of Assam, India.

\section{Methods}

\section{Plant material}

Fresh plant material (fronds) of C. gigantea was collected from Southern Assam. The identification of the fern was done by Miss Kathakali Nath using standard manual $[8,9]$ and was formally confirmed by Dr. M. K. Bhattacharya. It was also matched with the available herbarium of the species at Central National Herbarium of Botanical Survey of India, Calcutta. A voucher specimen of the fern has been deposited in the Karimganj College Herbarium, Karimganj, Assam bearing deposition number M. 1213.

\section{Extraction and fractionation}

With tap and subsequently by sterile water the fresh fronds were cleaned, which were then shad-dried and pounded to powder. For extraction $50 \mathrm{~g}$ of powdered plant material was added to three solvents $(500 \mathrm{ml})$ of increasing polarity (ethyl acetate, methanol and water) using soxlet evaporator [10]. Boiling method was adopted for preparation of water extract.

The ethyl acetate extract (most active extract) was fractionated by using silica gel coloumn chromatography with different ratios of solvents i.e., petroleum ether, ethyl acetate and methanol and the fractions were named as FR I (only petroleum ether), FR II (PE-90:EA-10), FR III (PE85:EA-10:MeOH-5), FR IV (PE-80:EA-20), FR V (PE-80: EA-10:MeOH-10) and FR VI (PE-75:EA-25). The collected fractions were then evaluated for their antibacterial activity [11].

\section{Micro-organisms}

The strains $(\mathrm{KKN})$ were isolated from Silchar Medical College and Hospital Silchar, India from the patients who were admitted or visited the clinics of the hospital. The samples were collected on recommendation of the clinician for routine culture and sensitivity in the Department of Microbiology of Silchar Medical College and Hospital. The investigators have collected the isolates from the above mentioned Department and characterized for ESBL producing E. coli (KKN5 and KKN 6) and MBL producing $P$. aeruginosa (KKN1 and KKN2) production using PCR based assay and sequencing. The same was done for characterization of MRSA (KKN3, KKN4, KKN10, KKN11, and KKN12) strains as well. E. coli ATCC 25922 and S. aureus ATCC 25923 and P. aeruginosa PAO1 were used as controls.

\section{Antibacterial activity of extracts and fractions from $C$. gigantea}

Determination of diameters of growth inhibition zones

Agar well diffusion method was used for determining the antibacterial activity of different extracts. Aided with sterile swab, each bacterial culture $\left(10^{5} \mathrm{cfu} / \mathrm{ml}\right)$ was spread on Mueller Hinton Agar plates. Followed by wells $(5 \mathrm{~mm}$ diameter) were punched in the agar medium where $20 \mu \mathrm{l}$ of extract was added along which same volume of dimethyl sulphoxide (DMSO) served as negative control and antibiotic discs of ampicillin $(10 \mu \mathrm{g})$ and ciprofloxacin $(5 \mu \mathrm{g})$ were used as positive control. The plates were then incubated and the zone of inhibition was measured in $\mathrm{mm}$ [12]. The test was carried out in triplicate.

The different fractions obtained were allowed to stand at room temperature till the solvent evaporated. The dried fractions were dissolved in di-methyl sulphoxide (DMSO) and used for screening the antibacterial activity against the reference strains of $E$. coli ATCC 25922, $P$. aeruginosa PAO1 and S. aureus ATCC 25923 by well diffusion method [11].

\section{Determination of minimum inhibitory concentrations (MIC) and determination of minimum bactericidal concentrations (MBC)}

Broth dilution method was performed for determination of MIC. Test tubes containing culture media along with different dilutions of extract i.e., $25-800 \mu \mathrm{g} / \mathrm{ml}$ dissolved in dimethyl sulphoxide (DMSO) was used. To each of the test tubes bacterial cultures $\left(10^{5} \mathrm{cfu} / \mathrm{ml}\right)$ were added. Positive control containing growth media with each 


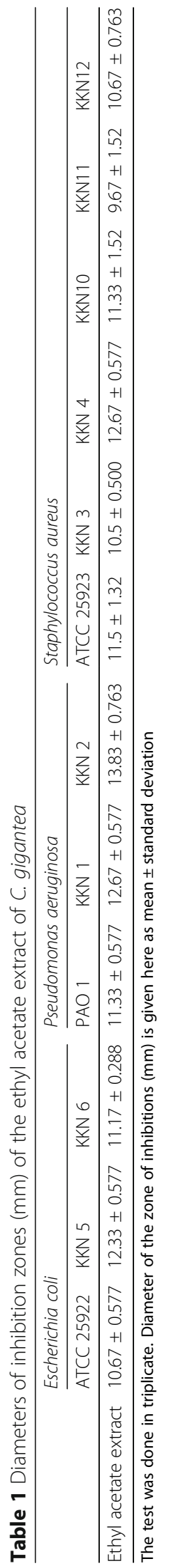


Table 2 Minimum inhibitory concentration (MIC) and Minimum bactericidal concentration (MBC)

\begin{tabular}{lll}
\hline Organisms & $\begin{array}{l}\text { Concentrations }(\mu \mathrm{g} / \mathrm{ml}) \\
\text { of ethyl acetate crude extract }\end{array}$ \\
\hline Staphylococcus aureus ATCC 25923 & MIC $200 \pm 0$ \\
& MBC $400 \pm 0$ \\
Escherichia coli ATCC 25922 & MIC $400 \pm 0$ \\
& MBC $800 \pm 0$ \\
Pseudomonas aeruginosa PAO1 & MIC $400 \pm 0$ \\
& MBC $800 \pm 0$ \\
\hline
\end{tabular}

organisms and negative control containing only extract and media was used [13]. The test was carried out in triplicate.

For determination of $\mathrm{MBC}$, test tubes from MIC study where no visible growth observed were subsequently sub-cultured $(100 \mu \mathrm{l})$ into agar medium [14]. The test was carried out in triplicate.

\section{Association of extracts with conventional antibiotics}

Bacterial culture of $10^{5} \mathrm{cfu} / \mathrm{ml}$ were seeded on Mueller Hinton agar plates to which antibiotic disc viz. ampicillin $(2 \mu \mathrm{g})$, ciprofloxacin $(5 \mu \mathrm{g})$, erythromycin $(15 \mu \mathrm{g})$, oxacillin $(1 \mu \mathrm{g})$ and tetracyclin $(30 \mu \mathrm{g})$ were placed. To each of the disc $6 \mu \mathrm{l}$ of extract $(1 \mathrm{x} \mathrm{MIC})$ was added. The plates were then incubated [15] and the results were interpreted as per CLSI guidelines 2015 [16]. The test was carried out in triplicate.

The FIC index of each antibiotic combined with extract was calculated using eq. 3 .

FIC A (extract) $=$ MIC of extract in combination

/MIC of extract alone

FIC B (antibiotic) $=$ MIC of antibiotic in combination

/MIC of antibiotic alone

The sum of FIC A and FIC B determines FIC index (eq. 3)

Table $3 \mathrm{FIC}$ index of the tested antibiotic

\begin{tabular}{lllll}
\hline FIC index & & & & \\
\hline Ampicillin & Ciprofloxacin & Erythromycin & Oxacillin & Tetracycline \\
\hline $1.125 \pm 0.11$ & $0.65 \pm 0.10$ & $0.96 \pm 0.11$ & $1.75 \pm 0$ & $0.96 \pm 0.10$ \\
$0.812 \pm 0.09$ & $0.57 \pm 0.08$ & $0.73 \pm 0.09$ & $1.12 \pm 0.11$ & $0.73 \pm 0.22$ \\
$0.656 \pm 0.12$ & $0.57 \pm 0.23$ & $0.73 \pm 0$ & $1.12 \pm 0$ & $0.73 \pm 0.12$ \\
$0.812 \pm 0.13$ & $0.57 \pm 0.12$ & $0.73 \pm 0$ & $1.12 \pm 0.11$ & $0.73 \pm 0.20$ \\
$0.656 \pm 0.11$ & $0.57 \pm 0.22$ & $0.73 \pm 0.21$ & $1.12 \pm 0$ & $0.73 \pm 0.09$ \\
$0.812 \pm 0.11$ & $0.57 \pm 0.15$ & $0.61 \pm 0$ & $0.81 \pm 0$ & $0.73 \pm 0$ \\
\hline
\end{tabular}

$$
\text { FIC index }=\text { FIC A }+ \text { FIC B }
$$

The effects of combination results into synergy, indifference, antagonism and additive and is defined as $\sum \mathrm{FIC} \leq 0.5, \Sigma \mathrm{FIC} \leq 4, \Sigma \mathrm{FIC}>4$ and $0.5 \sum \mathrm{FIC} \leq 1$ respectively

\section{Gas chromatography mass spectroscopy}

Gas chromatography mass spectroscopy was done at AIRF, Jawaharlal Nehru University, Delhi and was carried out with GCMS-QP2010 Plus, Shimadzu, Kyoto, Japan. The type of column used was RXi-5 Sil MS (30 m X $0.25 \mathrm{~mm}$ i.d. X $0.25 \mu \mathrm{m}$ film thickness) whose initial temperature was $60^{\circ} \mathrm{C}$ and the carrier gas used was helium. The compounds were identified using two libraries i.e., NIST14.lib and WILEY8.lib (Additional file 1).

\section{Statistical analysis}

All the values were expressed as mean \pm standard deviation of three replicates. Statistical significance was determined by $p$-value $<0.05$.

\section{Results}

The ethyl acetate, methanol and water extracts of $C$. gigantea were studied for their antibacterial activities against MDR bacteria. Of the three extracts, ethyl acetate extract was found to possess antibacterial activity especially against $E$. coli, $P$. aeruginosa, $S$. aureus as well as against reference strains, E. coli ATCC 25922 and S. aureus ATCC 25923. The diameters of inhibition zones varied from 11 to $13 \mathrm{~mm}$ and from 8 to $12 \mathrm{~mm}$ against Gram-negative and Gram-positive bacteria, respectively (Table 1 ).

Since the ethyl acetate extract of $C$. gigantea was found to possess significant antibacterial property so, the ethyl acetate extract was fractionated by column chromatography. The elution was done using petroleum ether, ethyl acetate and methanol in different ratios and six fractions were collected. A varying degree of antibacterial activity was observed with the FR II, FR III and FR IV fractions of ethyl acetate extract against all the tested organisms. Highest zone of inhibition was shown by FR IV fraction followed by FR II and FR III fraction in case of Gram-positive i.e., $S$. aureus, whereas in case of Gram-negative a consistent increase was observed from FR II to FR IV which was in accordance with increase in polarity of the solvent. However, FR I, FR V and FR VI did not show any antibacterial property.

The MIC assay was carried with ethyl acetate extract at $25 \mu \mathrm{g} / \mathrm{ml}, 50 \mu \mathrm{g} / \mathrm{ml}, 100 \mu \mathrm{g} / \mathrm{ml}, 200 \mu \mathrm{g} / \mathrm{ml}$, and $400 \mu \mathrm{g} /$ $\mathrm{ml}$ concentration. $200 \mu \mathrm{g} / \mathrm{ml}$ was found to be the MIC against S. aureus ATCC 25923 and $400 \mu \mathrm{g} / \mathrm{ml}$ was the 
Ethyl acetate extact of Cyathea gigantea

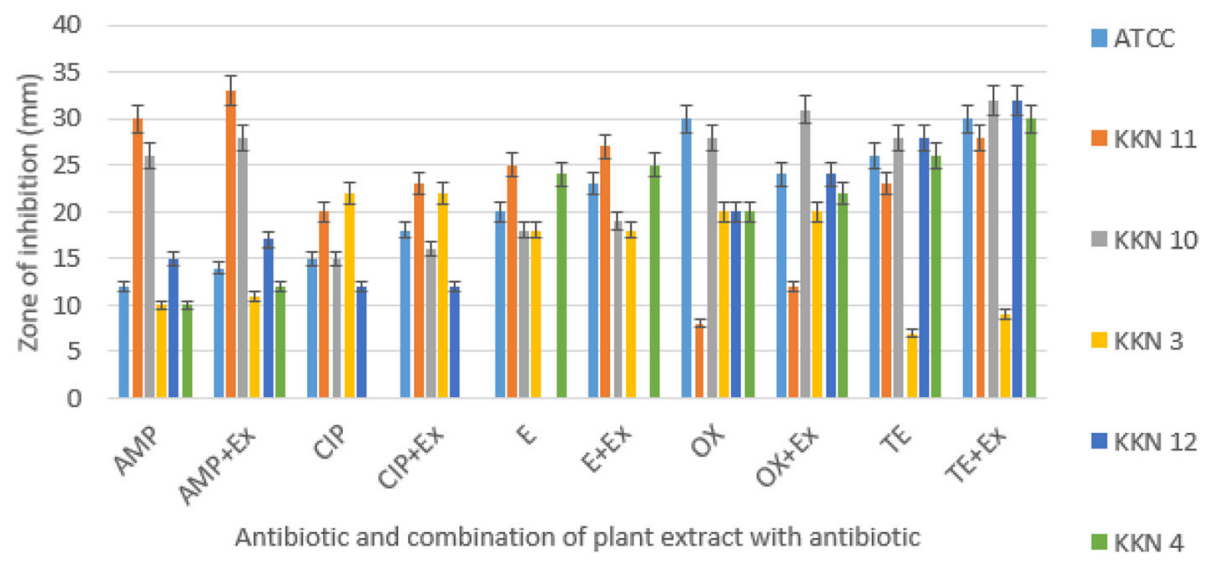

Fig. 1 Synergistic activity with the ethyl acetate crude extract against methicillin resistant Staphylococcus aureus

MIC against E. coli ATCC 25922 and P. aeruginosa PAO1 (Table 2).

The MBC values (Table 3) were found to be two-fold greater than the MIC values on the corresponding microorganisms.

The combination of the ethyl acetate extract of $C$. gigantea with conventional antibiotics: ampicillin, ciprofloxacin, erythromycin, oxacillin and tetracycline against methicillin resistant $S$. aureus (Fig. 1) and reference strain, $S$. aureus ATCC 25923, revealed that the antibacterial activity of all studied antibiotics increased in the presence of the plant extract. The FIC index of each antibiotic combined with extract was calculated using eq. 3 (Table 3). The analysis of results revealed synergistic effects with ciprofloxacin, tetracycline, ampicillin and oxacillin (Table 4).
The GC-MS analysis of the three fractions i.e., FR II, FR III and FR IV of Cyathea gigantea revealed the presence of 64 phytocomponents in total. Of which, on literature survey 11 phyto constituents i.e., Isophytol; N-Hexadecanoic acid; Phytol; N-Tetracosanol-1; 1-heptacosanol; Octacosanol; Hexadecanoic acid, 2hydroxy-1- (hydroxymethyl)ethyl ester; Octadecanoic acid; 1-eicosanol Cycloheptasiloxane, tetradecamethyland Neophytadiene (Table 5) were reported to possess antimicrobial property.

\section{Discussion}

The spread of drug-resistant microorganisms is a serious threat to successful therapy of microbial diseases. Therefore there is an urgent need to search new compounds characterized by diverse chemical structures and mechanisms of

Table 4 Diameters of inhibition zones $(\mathrm{mm})$ of fractions from C. gigantea ethyl acetate extract

\begin{tabular}{|c|c|c|c|c|c|c|c|c|c|}
\hline & \multicolumn{3}{|l|}{ FR II } & \multicolumn{3}{|l|}{ FR III } & \multicolumn{3}{|l|}{ FR IV } \\
\hline & 100 & 200 & 400 & 100 & 200 & 400 & 100 & 200 & 400 \\
\hline Staphylococcus aureus ATCC 25923 & $15.33 \pm .577$ & - & - & $10.5 \pm 0.5$ & - & - & $23.17 \pm .76$ & - & - \\
\hline KKN 3 & $12 \pm 1.5$ & - & - & $1.33 \pm 1.04$ & - & - & $21.5 \pm 1.32$ & - & - \\
\hline KKN 4 & $16.5 \pm 0.5$ & - & - & $8.67 \pm 1.15$ & - & - & $21.83 \pm 1.89$ & - & - \\
\hline KKN 10 & $11.33 \pm .288$ & - & - & $9.167 \pm 1.75$ & - & - & $22.33 \pm 1.52$ & - & - \\
\hline KKN 11 & $13.33 \pm .288$ & - & - & $11.33 \pm 1.52$ & - & - & $23.47 \pm .503$ & - & - \\
\hline KKN 12 & $12.167 \pm 1.755$ & - & - & $10.33 \pm .289$ & - & - & $20.33 \pm .577$ & - & - \\
\hline Escherichia coli ATCC 25922 & - & - & $7.167 \pm .751$ & - & - & $15.167 \pm 1.25$ & - & - & $24.5 \pm 0.5$ \\
\hline KKN 5 & - & - & $6.67 \pm 1.154$ & - & - & $13.13 \pm 1.20$ & - & - & $23.5 \pm .866$ \\
\hline KKN 6 & - & - & $6.83 \pm 1.44$ & - & - & $12 \pm 0.5$ & - & - & $22.467 \pm 1.36$ \\
\hline Pseudomonas aeruginosa PAO1 & - & - & $8.67 \pm .763$ & - & - & $11.33 \pm 1.52$ & - & - & $26.067 \pm .901$ \\
\hline KKN 1 & - & - & $9.33 \pm .288$ & - & - & $9.67 \pm .577$ & - & - & $23.83 \pm .763$ \\
\hline KKN 2 & - & - & $7.67 \pm .577$ & - & - & $9.5 \pm 0.5$ & - & - & $23.83 \pm 1.44$ \\
\hline
\end{tabular}




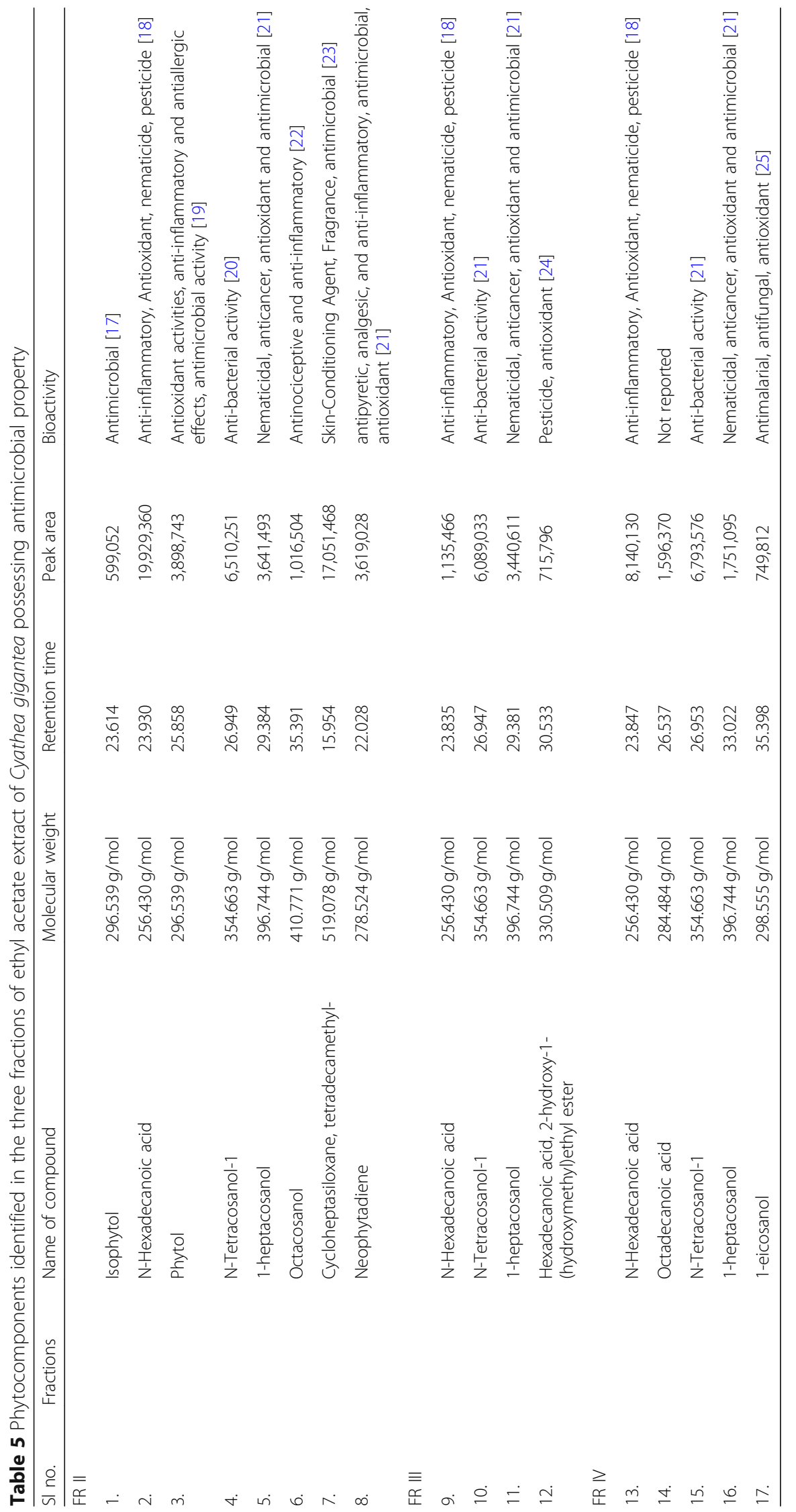


action. Plants are rich in a wide variety of secondary metabolites such as tannins, terpenoids, alkaloids and flavonoids which have been found in vitro to possess antimicrobial properties.

C. gigantea, a tree fern belonging to the family Cyatheaceae, possesses immense and diverse ethnomedicinal importance [3-5]. Preliminary phytochemical analysis of different extract of the fern was carried out which have brought foreword the presence of various bioactive secondary metabolites viz., steroids, alkaloids, phenolic groups, cardiac glycosides, flavonoids, saponins, tannins and terpenoids [26]. This presence of bioactive secondary metabolites has investigated to study the plant for its various bioactivity. In this study the antibacterial activity of $C$. gigantea is evaluated. Ethyl acetate extract was recorded to be the active extract against all the tested organisms and this might be due to the presence of various phytochemicals. The antimicrobial property also may be due to the presence of coumarin, which is an antimicrobial agent naturally present in plant [27]. In addition some other isolated compounds viz., 2methylbutane-1,4-diol, 3-(1-ethoxyethoxy) may also impart to the antibacterial property of the plant [26].

The fractionated crude ethyl acetate extract also showed potential antibacterial activity against both Gram-positive and Gram-negative. Of the six fractions, FR II, FR III and FR IV exhibited antibacterial property while FR I, FR V and FR VI did not show any activity. The fractions (FR II, FR III and FR IV) showed significant variations in their inhibition zones against the studied organisms.

The MIC was found to be $200 \mu \mathrm{g} / \mathrm{ml}$ against Grampositive and $400 \mu \mathrm{g} / \mathrm{ml}$ against Gram-negative bacteria. The efficacy of the extract is determined by its MIC value. Extracts having MIC value lesser than $1000 \mu \mathrm{g}$ of crude extracts or $100 \mu \mathrm{g}$ of isolated compounds is considered to be effective concentration. In the study the MIC value varied from 200 to $400 \mu \mathrm{g} /$ $\mathrm{ml}$ against the tested bacteria indicating the fern to be an effective antibacterial agent. The higher MIC against Gram-negative i.e., E. coli ATCC 25922 and P. aeruginosa $\mathrm{PAO} 1$ in comparison to $S$. aureus ATCC 25923 may be due to the presence of outer membrane in their cell wall [28].

The differences in MBC and MIC suggests that the extract possesses a selective antibacterial property. The extract was found to show good bactericidal activity against the tested organisms as the ratio of $\mathrm{MBC} / \mathrm{MIC}$ was equals to 2 [29].

The present study also focused on the combined effect of ethyl acetate extract and antibiotics. The results revealed the synergistic and additive interactions between the phytochemicals present in the ethyl acetate extract and antibiotics, which are cell wall inhibitors (ampicillin, oxacillin), protein synthesis inhibitor (erythromycin, tetracycline) and DNA synthesis inhibitor (ciprofloxacin). The FIC index showed that significant synergistic activity was shown by ciprofloxacin followed by tetracycline, ampicillin and oxacillin.

\section{Conclusion}

Extracts of C. gigantea showed activity against both Gram-positive and Gram-negative organisms and thus offers the scientific basis for the traditional use of the fern. The study also highlighted that FR IV of ethyl acetate extract of $C$. gigantea showed the highest antibacterial activity which is due to the presence of various active phytochemicals with high peak area shown in GCMS. The present study also provides the basis for future study to validate the possible use against multidrug resistant organisms.

\section{Supplementary information}

Supplementary information accompanies this paper at https://doi.org/10. 1186/s12906-019-2696-0.

Additional file 1. Identifying High Risk Areas of Zika Virus Infection by Meteorological Factors in Colombia

\section{Abbreviations}

CLSI: Clinical Laboratory Standard Institute; DMSO: Dimethyl Sulphoxide; EA: Ethyl Acetate; ESBL: Extended Spectrum Beta Lactamase; FIC: Fractional Inhibitory Concentration; GCMS: Gas Chromatography Mass Spectroscopy; MBC: Minimum Bactericidal Concentration; MBL: Metallo Beta Lactamase; MDR: Multi Drug Resistant; MeOH: Methanol; MIC: Minimum Inhibitory Concentration; MRSA: Methicillin Resistant Staphylococcus aureus; PCR: Polymerase Chain Reaction; PE: Petroleum Ether; TLC: Thin Layer Chromatography

\section{Acknowledgements}

The authors acknowledge the Department of Microbiology, Assam University for providing the infra-structure facility and also Assam University Biotech Hub and Karimganj College Biotech Hub for providing laboratory facility to complete this work. The authors are also thankful to Dr. Ajai Kumar, Incharge GC-MS Facility, Advanced Instrumentation Research Facility (AIRF), Jawaharlal Nehru University, New Delhi for GC-MS analysis.

\section{Authors' contributions}

All authors have read and approved the manuscript. KN-Carried out the experimental work and prepared the manuscript. ADT- Supervised and designed the work and corrected the manuscript. MKB- Supervised the collection and identification of samples and preparation of manuscript. DBCarried out the experimental work of this manuscript with reference to isolation, characterisation and resistance analysis of all the Gram positive organisms used in the study. SC-Carried out molecular biological experiment and expression analysis of resistance organisms. DC- Interpreted the data, prepared the manuscript and its editing. AM-Carried out experimental work of the manuscript with special reference to fern extract preparation. NAC Performed a part of experiment and prepared manuscript.

\section{Authors' information}

KN, DB, SC, DC, AM, NAC- Research scholar of Assam University, Silchar. ADT- Faculty, Department of Life Science and Bio-informatics, Assam University, Silchar.

MKB- Faculty, Department of Botany and Biotechnology, Karimganj College, Karimganj. 


\section{Funding}

Assam University, Silchar. The funding body has no role in study design, collection, analysis, data interpretation and in writing the manuscript.

\section{Availability of data and materials}

The datasets used and/or analysed during the current study available from the corresponding author on reasonable request.

\section{Ethics approval and consent to participate}

Not applicable.

\section{Consent for publication}

Not applicable.

\section{Competing interests}

The authors declare that they have no competing interests.

\section{Author details}

'Department of Microbiology, Assam University, Silchar, India. ${ }^{2}$ Department of Life Science and Bio informatics, Assam University, Silchar, India. ${ }^{3}$ Department of Botany and Biotechnology, Karimganj College, Karimganj, India.

\section{Received: 12 January 2019 Accepted: 25 September 2019}

\section{Published online: 22 October 2019}

\section{References}

1. Newman DJ, Craqq GM. Natural products as sources of new drugs over the last 25 years. J Nat Prod. 2007;70(3):461-77.

2. Dey P, Sen A, Bhattacharya MK, Pasha MK. A review of the ferns of Barak Valley, Assam, India. J Taxon Biodiv. 2011;5:33-42.

3. Das S, DuttaChoudhury M. Ethnomedicinal Uses of Pteridophytes of West Tripura District, India. In: DuttaChoudhury M, Sharma GD, Talukdar AD, Choudhury S, editors. Researches in Medicinal And Aromatic Plants: Swastik Publication; 2012.

4. Shil S, DuttaChoudhury M. Ethnomedicinal importance of Pteridophytes used by Reang tribe of Tripura, North East India. Ethnobotanical Leaflets. 2009;13:634-43.

5. DuttaChoudhury M, Das B, Mazumder PB. Fern Flora and Fern allies of southern Assam- ethno-medico botanical studies and certain conservation aspects. Udaipur: Scichem Publishing House; 2009.

6. Juneja RK, Sharma SC, Tandon JS. Studies on a Fern, Cyathea gigantea. Int J Crude Drug Res. 1990;28(3):161-2.

7. Das Talukdar A, DuttaChoudhury M, Chakraborty M, Dutta BK Phytochemical screening and TLC profiling of plant extracts of Cyathea gigantea (Wall. Ex. Hook.) Haltt. and Cyathea brunoniana. Wall. ex. Hook. (Cl. \& Bak.). Assam Univ J Sci Technol Biol Environ Sci. 2010;5:70-4.

8. Beddome RH. Handbook of the Ferns of British India, Ceylon and Malaya Peninsula. Thackar and Spink Co. Calcutta. Xiv, 1892, 110p. illust.

9. Borthakur S, Deka P. Nath KK. The illustrated manual of ferns of Assam Dehradun: Bishen Singh Mahendra Pal Singh; 2001.

10. Bobbarala W, Katikala PK, Naidu KC, Penumajii S. Antifungal activity of selected plant extracts against phytopathogenic fungi Aspergillus Niger F2723. Indian J Sci Technol. 2009;2:6839-46.

11. Lawrence R, Tripathi $P$, Jeyakumar E. Isolation, purification and evaluation of antibacterial agents from Aloe vera. Braz J Microbiol. 2009;40:906-15

12. Dahiya P, Purkayastha S. Phytochemical screening and antimicrobial activities of some medicinal plants against multi-drug resistant bacteria from clinical isolates. Indian J Pharm Sci. 2012;74(5):443-50

13. Thomas T. Preliminary antibacterial evaluation of fronds of Pteris quadriaurita Retz. Towards bacteria involved in dermatological diseases. J Appl Pharm Sci. 2011;01(08):214-6.

14. Ratimi VO, Laughon BE, Barlet JS, Mosadomi HA. Activities of Nigerian chewing sticks extracts against Bacterioidesgingivalis and Bacterioidesmelaninogenicus. Antimicrob Agents Chemother. 1998:32:598-600.

15. Moussaoui F, Alaoui T. Evaluation of antibacterial activity and synergistic effect between antibiotic and the essential oils of some medicinal plants. Asian Pac J Trop Biomed. 2016:6(1):32-7.

16. Clinical and laboratory standards institute. Performance standards for antimicrobial susceptibility testing $25^{\text {th }}$ informational supplement M100-S24. Wayne: CLSI; 2015
17. Tao R, Wang CZ, Kong ZW. Antibacterial/antifungal activity and synergistic interactions between Polyprenols and other lipids isolated from ginkgo Biloba L. Leaves Molecules. 2013;18:2166-82.

18. Mustapha NA, Runner RTM. GC-MS analysis and preliminary antimicrobial activity of Albizia adianthifolia (Schumach) and Pterocarpus angolensis (DC). Medicines. 2016;3(1):3.

19. de Moraes J, de Oliveira RN, Costa JP, Junior ALG, de Sousa DP, Freitas RM et al. Phytol, a Diterpene alcohol from chlorophyll, as a drug against neglected tropical disease Schistosomiasis Mansoni. PLoS Negl Trop Dis. 2014;8:1.

20. Kuppuswamy KM, Jonnalagadda B, Arockiasamy S. GC-MS analysis of chloroform extract of croton bonplandianum. Int J Pharm Bio Sci. 2013;4(4):613-7.

21. Venkata RB, La S, Saradhi PM, Rao NB, Krishna ANV, Tm R. Antibacterial, antioxidant activity and GC-MS analysis of Eupatorium odoratum. Asian J Pharm Clin Res. 2012:5(Suppl 2):99-106

22. Oliveira AM, Conserva LM, de Souza Ferro JN, de Almeida BF, Lyra Lemos $\mathrm{RP}$, Barreto E. Antinociceptive and anti-inflammatory effects of Octacosanol from the leaves of Sabicea grisea var. grisea in mice. Int J Mol Sci. 2012;13(2): 1598-611.

23. Chaudhary $\mathrm{R}$, Tripathy A. Isolation and identification of bioactive compounds from Irpex Lacteus wild fleshy Fungi. J Pharm Sci Res. 2015;7(7):424-34.

24. Tyagi T, Agarwal M. Phytochemical screening and GC-MS analysis of bioactive constituents in the ethanolic extract of Pistia stratiotes L. and Eichhornia crassipes (Mart) Solms. J Pharmacogn Phytochem. 2017:6(1):195-206.

25. Sadhu S, Ram V, Aadesariya M, Dave P, Khosla E. A study on phytoconstituents, bioactivity, uses: analysis of acetonitrile leaf extract of Abutilonpannosum with gas chromatography mass spectrometric technique. J Pharm Sci. 2016:5(4):8-21.

26. Narayanan J, Antonysamy JM. HPTLC fingerprint profile (Phenolics) of selected Cyathea species from Western Ghats, South India. Chinese J Biol. 2016;2016:7.

27. Janakiraman N, Johnson M. Inter specific variation studies on Cyathea species using phyto-chemical and fluorescence analysis. Res Rev: J Pharm Toxicol Stud. 2015;3:25-31.

28. Delcour AH. Outer membrane permeability and antibiotic resistance. Biochima et Biophysica Acta (BBA). 2009;1794(5):808-16.

29. Olajuyigbe $\mathrm{OO}$, Afolayan AJ. In vitro pharmacological activity of the crude acetone extract of ErythrinacaffraThunb: antibacterial and antifungal assessment. J Med Plants Res. 2012:6(9):1713-20.

\section{Publisher's Note}

Springer Nature remains neutral with regard to jurisdictional claims in published maps and institutional affiliations.

Ready to submit your research? Choose BMC and benefit from:

- fast, convenient online submission

- thorough peer review by experienced researchers in your field

- rapid publication on acceptance

- support for research data, including large and complex data types

- gold Open Access which fosters wider collaboration and increased citations

- maximum visibility for your research: over $100 \mathrm{M}$ website views per year

At $\mathrm{BMC}$, research is always in progress.

Learn more biomedcentral.com/submissions 